\title{
A REVIEW OF SHADE TREE NITROGEN FERTILIZATION RESEARCH IN THE UNITED STATES
}

\author{
by Daniel K. Struve
}

\begin{abstract}
Shade tree nitrogen fertilization research in the United States, beginning in the 1920s, is reviewed. The early empirical studies demonstrated that shade tree growth increased in response to $\mathrm{N}$ applications, that $\mathrm{N}$ source did not significantly affect growth; that surface applications were as effective as soil injection or drilling, and that $\mathrm{N}$ application rates of $29 \mathrm{~g} \mathrm{~N} / \mathrm{m}^{2}\left(6 \mathrm{lb} / 100 \mathrm{ft}^{2}\right)$ were near optimal. Also, resulting from these studies were recommendations for dormant-season (early spring, late fall) $\mathrm{N}$ application times. The trees in these studies were planted on relatively close spacings and the experiments were conducted over long periods of time. Thus, the results were most likely confounded by "shared root zones." Due to root growth out of the "treated" areas and into adjacent plots, roots from a single tree could be exposed to two or more treatments. Two additional confounding factors were that many studies were established on soils with high native fertility and that grass competed for water and nutrients. These factors may explain the general absence of treatment differences in these studies. Later studies conducted with ${ }^{15} \mathrm{~N}$ showed low $\mathrm{N}$ uptake during the dormant (leafless) season, bringing into question the practice of dormant-season $\mathrm{N}$ applications. Additional research is needed with tree-lawn systems to define $\mathrm{N}$ uptake patterns, seasonal $\mathrm{N}$ uptake potential, and $\mathrm{N} \mathrm{cy-}$ cling among the system's components.
\end{abstract}

Key Words. Nitrogen uptake; nitrogen utilization efficiency; nitrogen application.

Tree nutrition and fertilization practices are topics of interest to arborists, municipal foresters, and nursery producers. Despite the high interest level, research supporting current practices is far from complete (Darrah 2000) and subject to debate; see articles by Caldwell (pp 9-13), Lanphear (pp 143-150), and Miller (pp 15-19) in the Tree and Shrub Fertilization proceedings (Siewert et al. 2000). A conference on tree and shrub fertilization was organized to assess the current understanding of tree and shrub response to fertilizer application and to begin working toward prescriptive mineral nutrition programs. During the conference, I began to wonder from which studies were the current fertilization recommendations developed? This paper reviews the early empirical field research from which the current tree nutrition recommendations were developed and more recent studies that suggest that the current recommendations be revisited.

\section{EMPIRICAL STUDIES}

"Volumes galore have been written about fertilizers of all sorts and their effects upon farm crops, vegetables, and flowering plants. Innumerable experiments carried out over extended periods of time have furnished the information on which modern fertilizing practices are based. Yet strangely enough, practically nothing of value is known concerning the proper method of feeding ornamental or shade trees" (Bielmann 1929, p 119).

\section{A.P. Bielmann}

The preceding comment opens Bielmann's literature review on tree nutrition (Bielmann 1929). He asked: Are the nutrition requirements similar for all tree species? Do trees not subject to cultivation respond to feeding (fertilization)? What fertilizer should be used? What time of the year is fertilizing most beneficial? How often and in what quantity should trees be fertilized? He used the popular term "feeding," acknowledging that trees do not have to be fed mineral nutrients.

Bielmann noted Moeller's (1908) observations that growth of the main stem (caliper growth) depends on the nutritive conditions of the previous year, while the length, thickness, and color of the leaves depend on the nutritive conditions of the current year. Bielmann cited Charlton's (1927) recommendations, developed for the Dallas, Texas, U.S., Park Commission, that $\mathrm{N}$ fertilizers be applied at specific times: either in early spring as the new season's growth begins or at the onset of dry weather before the trees experience significant drought stress. Fertilizers should not be applied after August 10 in the Dallas area so that new growth is not stimulated. 
Bielmann notes there are numerous fertilizer application recommendations, but none are supported by experimental evidence. For instance, Mulford's recommendation (first made in 1921, but also contained in the revised 1937 Bulletin) that trees be fertilized with $3.8 \mathrm{~L}$ (1 gal) to $95.0 \mathrm{~L}$ ( $25 \mathrm{gal}$ ) (depending on tree size) of a solution made of $454 \mathrm{~g}(1 \mathrm{lb})$ of nitrate of soda in $190 \mathrm{~L}$ (50 gal) of water, was made without supporting data. Mulford's fertilizer rate represents 1.7 to $43.1 \mathrm{~g}$ (0.0077 to $0.095 \mathrm{lb}$ ) $\mathrm{N}$ per tree. Because of the conflicting recommendations and little experimental evidence, he began long-term fertilizer trials at the Missouri Botanical Garden.

Bielmann's first research report appeared in 1934 (Bielmann 1934; see Table 1 at the end of this article for a summary of the pre-1990 field tree $\mathrm{N}$ research). $\mathrm{He}$ cited starvation (lack of mineral nutrition) and soil compaction as the most common causes of mature shade tree death. Bielmann contrasts forests, where trees evolved under conditions of nutrient cycling and uncompacted soils, with typical park or residential sites. Tree starvation in parks and residential conditions was caused by nutrient removal (leaves are raked and burned off-site) and soil compaction (lawns are rolled). The negative effects were expressed as reduced twig extension. His tree vigor ratings (and by implication, tree mineral nutrition status) were based on annual twig extension: $10 \mathrm{~cm}$ (4 in.) of twig indicates a starved tree, 15 to $20 \mathrm{~cm}(6$ to 8 in.) indicates a tree that needs some feeding, and more than $30 \mathrm{~cm}$ (12 in.) indicates a vigorous tree not needing feeding. These general recommendations were made without allowance for possible innate differences in growth rates among species.

His experimental method was not fully detailed. His initial plots were double rows of green ash (Fraxinus pennsylvanica) and black walnuts (Juglans nigra), 18 and 25 trees, respectively. The trees were grown in sod. His experimental method was to spring-broadcast various fertilizer treatments to the trees. He used current season's growth, relative to last season's growth, to express his results, thus eliminating the need for "check trees." The best fertilizer treatment from the current year was used as the standard treatment the following year along with a series of new treatments. This process was repeated for five seasons. He gave an example of his experimental method for ginkgo (Bielmann 1934, p 116). He applied $2.27 \mathrm{~kg}(5 \mathrm{lb})$ of $4-8-4$ in the first year, increas- ing the amount of fertilizer and the N-P-K content of the fertilizer for the next four years, reaching his annual recommendation of $11.35 \mathrm{~kg}(25 \mathrm{lb})$ of 10-8-6 applied under the drip line per tree per year.

$\mathrm{He}$ gave a formula for fertilizer application based on tree canopy volume and trunk circumference. Tree height (in feet) was added to branch spread diameter (in feet), and this sum was added to the trunk circumference (in inches) at breast height giving the pounds of 10-8-6 fertilizer to broadcast under the drip line. His example, a tree $35 \mathrm{ft}(11 \mathrm{~m})$ tall, with a $30-\mathrm{ft}(9.2-\mathrm{m})$ branch spread diameter and a 38 -in. $(96.5-\mathrm{cm})$ trunk circumference would receive $103 \mathrm{lb}(46.7 \mathrm{~kg})$ of 10-8-6 fertilizer annually; the equivalent of $10.3 \mathrm{lb}(4.7 \mathrm{~kg}) \mathrm{N}$ applied over $707 \mathrm{ft}^{2}\left(6.8 \mathrm{~m}^{2}\right)$, or $14.6 \mathrm{lb}(6.6 \mathrm{~kg}) \mathrm{N} /$ $1,000 \mathrm{ft}^{2}\left(9.29 \mathrm{~m}^{2}\right)$ or $1.5 \mathrm{lb} \mathrm{N} /$ inch $(268 \mathrm{~g} / \mathrm{cm})$ trunk caliper. This rate was adjusted for crown form. Trees with high, narrow crowns (like those found in a closed forest) would receive one-half the amount of an opengrown tree with low branches, while a limbed-up, open-grown tree (like one on a city street) would receive two-thirds the amount.

$\mathrm{He}$ also explored methods of fertilizer application: deep root [41 to $46 \mathrm{~cm}$ (16 to $18 \mathrm{in}$.)] fertilizing by the "punch bar" method for dry fertilizers and by the "watering needle" for water-soluble fertilizers. In general, there was no benefit from the deep-root feeding methods over broadcast applications. He noted that transplanted trees respond to fertilizer in the growing season after fertilizer application and that fertilizer was best applied between April 1 and July 1 in Missouri.

Bielmann's (1936) third paper updated the 1934 paper. The annual fertilizer application rate example based on adding height, crown diameter, and caliper, used a larger tree than his 1934 example; it was $80 \mathrm{ft}$ $(24.6 \mathrm{~m})$ tall, $60 \mathrm{ft}(18.5 \mathrm{~m})$ in diameter, and $125 \mathrm{in}$. $(49.2 \mathrm{~cm})$ in circumference. This tree would annually receive $265 \mathrm{lb}(120 \mathrm{~kg})$ of 10-8-6 broadcast under the drip line-an equivalent of $26.5 \mathrm{lb}(12.0 \mathrm{~kg}) \mathrm{N}$ over $2,827 \mathrm{ft}^{2}\left(262.6 \mathrm{~m}^{2}\right)$ or $9.4 \mathrm{lb} \mathrm{N} / 1,000 \mathrm{ft}^{2}(4.2 \mathrm{~kg} / 92.9$ $\left.\mathrm{m}^{2}\right)$ or $0.75 \mathrm{lb} \mathrm{N} /$ in. $(134 \mathrm{~g} / \mathrm{cm})$ trunk caliper.

\section{Wyman}

Wyman began his Ph.D. research on pin oak (Quercus palustris) transplanting and fertilizing methods at Cornell University, Ithaca, New York, U.S., in 1929 (Wyman 1936). Only pin oak response to fertilizer will be reviewed in this paper. The study used 1.3cm (0.5-in.) caliper, five-year-old pin oaks, grown 
from the same seed lot and selected for uniformity. They were planted on two soil types: a Dunkirk stony clay and a Dunkirk silty clay loam. About 400 trees were planted on 3.7-m (12-ft) centers. After planting was completed in spring 1931, the site was sown to Kentucky bluegrass. Trees were fertilized with either ammo-phos (11-46-0) or ammonium sulfate (20-0-0). Control trees received no fertilizer. The 0.5 -in. caliper trees were fertilized with the equivalent of $227 \mathrm{~g}$ ( 0.5 lb) ammonium sulfate per tree $[35.6 \mathrm{~g} / \mathrm{cm}(0.2 \mathrm{lb} \mathrm{N} /$ in.) trunk caliper] in spring (beginning May 1). The fertilizer was broadcast at $0.8-\mathrm{m}(2.5-\mathrm{ft})$ radius from the trunk in three applications made at two- to threeweek intervals. The fertilizer treatments were repeated annually for four years.

There was no response to fertilizer application in the first year after transplanting. Selected harvesting revealed that the fertilizer was placed too far from the tree's roots. Regenerating roots tended to grow straight down with little horizontal growth. Fertilized trees grew more rapidly (as measured by total shoot extension per tree) in the second, third, and fourth years after transplanting than unfertilized trees, with more growth resulting from ammo-phos than ammonium sulfate fertilizer. A second growth flush was common in fertilized trees but uncommon in unfertilized trees. The second growth flush was responsible for most of the growth differences between fertilized and unfertilized trees because the spring growth flushes were similar in fertilized and unfertilized trees. Trees fertilized once in 1932 grew more in the next three years than unfertilized trees, with similar growth in the fourth year, indicating a three-year residual fertilizer effect. Fertilized trees had higher foliar $\mathrm{N}$ concentrations than unfertilized trees, $1.12 \%$ to $1.81 \%, 2.35 \%$ to $2.79 \%$, and $2.00 \%$ to $2.77 \%$ foliar $\mathrm{N}$ for control, ammonia sulfate and ammo-phos fertilized trees, respectively. Trees grew more on the silty-clay loam soil than on the stony-clay soil.

\section{A.M.S. Pridham}

Pridham (1938) published the seven-year results from Wyman's study. It is not clear from the materials and methods if annual fertilizer treatments were continued. However, for fall-transplanted trees, fertilized trees had greater caliper than unfertilized trees on both soil types. For spring-transplanted trees, there was no difference between fertilized and unfertilized trees on either soil type.
Pridham $(1940,1941)$ also reported on the response to ammonium sulfate fertilizer by mature American elm (Ulmus americana) and red oak (Quercus rubra) trees grown in a lawn. The American elm study was begun in 1934. The plants received the equivalent of either 227 or $454 \mathrm{~g} \mathrm{~N}$ (0.5 or $1 \mathrm{lb}$; it isn't clear in the paper) ammonium sulfate fertilizer [17.9 to $35.7 \mathrm{~g} / \mathrm{cm}$ $\mathrm{N} /$ in. caliper $(0.1$ or $0.2 \mathrm{lb})]$. The trees ranged from 91 to $330 \mathrm{~cm}$ (36 to 130 in.) diameter at breast height (dbh). The fertilizer was broadcast under the drip line or placed in holes under the drip line. It is not stated if there was a single or annual fertilizer applications. There was no benefit from fertilizer; caliper of fertilized trees wasn't increased (relative to unfertilized plants) and no increase in foliage "greenness" was noted. He noted that percentage increase in trunk diameter decreased with increasing tree size, concluding that caliper growth slows with age and that large-caliper trees were unresponsive to fertilizer applications. Differential caliper growth attributed to tree size may have masked a fertilizer response. However, this finding cannot be checked because fertilizer treatment means were not presented. Basal area at breast height increase (a function of trunk volume) may be a better method of expressing growth in large-caliper trees than the percentage increase in $\mathrm{dbh}$. If his data are plotted, basal area at breast height increased with increasing tree caliper.

In the red oak study, 110 trees were grouped in caliper size classes of 10 to $25 \mathrm{~cm}$ (4 to $10 \mathrm{in}$.) and 51 to $102 \mathrm{~cm}$ (20 to $40 \mathrm{in}$.). Trees within each size class were given one of five treatments: untreated, 6-8-4 either broadcasted or drilled, or ammonium sulfate either broadcasted or drilled. All trees were treated at the rate of $23.2 \mathrm{~g} / \mathrm{cm}(0.13 \mathrm{lb} \mathrm{N} / \mathrm{in}$.) caliper in each of four years. Large-caliper trees [51 to $102 \mathrm{~cm}$ (20 to 40 in.)] were unresponsive to fertilizer. For smallcaliper trees, caliper increases, expressed as percentage increase from initial caliper, ranged from $70 \%$ (broadcast ammonium sulfate) to $30 \%$ (broadcasting 6-8-4); untreated trees increased caliper by $58 \%$. All fertilized trees had greener foliage and retained leaves later in fall than unfertilized trees.

\section{L.C. Chadwick}

Chadwick published three major nutrition studies (Chadwick 1934, 1936; Chadwick et al. 1950). The first experiment (Chadwick 1934, 1936) was initiated in 1931 when a block of 500 Moline elms (Ulmus 
americana 'Moline'), 2.2 to $2.5 \mathrm{~m}$ (7 to $8 \mathrm{ft}$ ) tall and about $1.9 \mathrm{~cm}$ (0.75 in.) in diameter, were planted on a 2.5 by $3.1 \mathrm{~m}$ ( 8 by $10 \mathrm{ft}$ ) spacing. The site had a silt loam soil and was previously planted in alfalfa. The site was clean cultivated during the experiment. The 500 trees were divided into four sections. Within each section, fertilizer was applied in spring only, spring and July, July and fall, or fall only. Each section was further divided into five subplots of 25 trees each. Five trees within each subplot received one of five treatments: control, 12-6-4 (inorganic fertilizer), 6-6-4 (organic fertilizer), ammonium sulphate, and ammonium sulfate plus superphosphate. There were 25 trees per treatment. The trees were fertilized annually between 1932 to 1934 at the rate of $17.5 \mathrm{~g} / \mathrm{cm} \mathrm{N}$ (0.25 lb/in.) trunk caliper by broadcasting the fertilizer around the trunk in a $0.9-\mathrm{m}(3-\mathrm{ft})$ diameter circle.

The two year results "... showed little consistency in reaction for a single type of fertilizer applied at different periods of the year" (Chadwick 1934, p 357). However, he states that fall-applied fertilizer gave the greatest increase in trunk caliper [0.76 cm, $(0.3$ in.)]; spring-applied fertilizer gave the least increase $[0.55 \mathrm{~cm}$, (0.25 in.)] in two years. Ammonium sulfate plus superphosphate and 12-6-4 fertilizer resulted in the largest caliper increase, $0.71 \mathrm{~cm}$ and 0.72 (0.25 in.), respectively. The study coincided with a drought; inadequate rainfall was cited for the lack of tree response to the spring-applied fertilizer. The site also had high fertility. Wooster silt loam soil is known as a productive soil type and the preceding alfalfa crop added $\mathrm{N}$ to the site. Unfortunately, no soil analysis was reported.

After four years, minor differences among the fertilizer treatments were found (Chadwick 1936). For instance, fall-fertilized trees had the greatest caliper increase and control trees the least, but the difference was only $0.46 \mathrm{~cm}$ (0.18 in.) over four years. The 12-6-4 fertilized trees had the greatest trunk caliper increase $[1.26 \mathrm{~cm}(0.5 \mathrm{in})$.$] ; trees fertilized with ammonium$ sulfate the least $[1.04 \mathrm{~cm}(0.4 \mathrm{in})$.$] . In addition to the$ reasons cited for the lack of response in the two-year results, "shared treatments" can be added. For instance, if roots grew $45.7 \mathrm{~cm}$ (18 in.) annually in USDA Plant Hardiness Zone 5, then the root system radius would be $1.8 \mathrm{~m}(6 \mathrm{ft})$, wide enough to overlap adjacent plots.

A second study was initiated in 1941 (Chadwick et al. 1950). Norway maples (Acer platanoides) were planted in 1935 as part of an insect borer study. The original design had 54 blocks of 16 trees each planted on 2.5-m (8-ft) centers. The site's soils were of the Wooster series and Muskingum silt loam, typified as being formed from sandstone and shale formations with good natural drainage. The site was relatively infertile; no available nitrate $\mathrm{N}$, low to medium phosphorus and, at most, a trace of available potassium; $\mathrm{pH}$ averaged 5.3. The sod ground cover was mowed occasionally. There were 430 trees with dbh of $3.8 \mathrm{~cm}$ (1.5 in.) available for the study.

Twenty fertilizer treatments were applied; all but eight were replicated. Treatments were applied in April 1941 and repeated in May 1947. Trees were fertilized at the rate of $44 \mathrm{~g} \mathrm{~N} / \mathrm{cm}(0.25 \mathrm{lb} \mathrm{N} /$ in. $)$ trunk caliper. The experiment was designed to test the effect of fertilizer type, rate, and method of application.

Unfertilized trees increased $3.9 \mathrm{~cm}$ (1.53 in.) in dbh during the six-year study. Trees treated with a 5.1 - to $7.6-\mathrm{cm}$ (2- to 3 -in.) layer of stable manure plus 10-6-4 had the greatest increase in dbh, $7.5 \mathrm{~cm}$ (3.0 in.). Trees treated with surface-applied 10-6-4 increased trunk caliper $6.3 \mathrm{~cm}$ (2.5 in.). Nitrogen was found to be the most limiting element on the site. The experimental design represents an improvement over the previous study. The block design reduced but didn't eliminate the likelihood of "shared" root space, and tree response to fertilizer was more pronounced due to low site fertility.

\section{Neely, Himelick, and Crowley, Jr.}

The largest shade tree fertilizer study conducted was initiated in 1963 (Neely et al. 1965, 1970). They begin their report by stating, "It was recognized, however, that the procedures for fertilizing established trees had not been thoroughly subject to scientific evaluation; more experimental data were needed." (Neely et al. 1970, p 235). This situation was similar to that described by Bielmann 34 years earlier. Three experiments conducted at The Morton Arboretum in Lisle, Illinois, U.S., will be presented: the effect of fertilizer type and application method, the effect of fertilizer type and application time, and the effect of fertilizer type and rate of application.

The effect of fertilizer type and application method study used three 100 tree blocks, one each for pin oak (Quercus palustris), white ash (Fraxinus americana), and honeylocust (Gledistia triacanthos var. inermis). The blocks were planted in 1956 (oak and ash) and 1957 (honeylocust) on 4.6 by $6.2 \mathrm{~m}$ (15 by $20 \mathrm{ft})$ centers. Kentucky bluegrass sod was established 
under the trees. The soils were fully characterized; most were silt loams.

Trees within each species were subject to one of 16 treatment combinations beginning in 1963 (six years after planting). Fertilizer was applied over $9.3 \mathrm{~m}^{2}$ $\left(100 \mathrm{ft}^{2}\right)$ at the rate of $26.9 \mathrm{~g} \mathrm{~N} / \mathrm{m}^{2}$ [6 lb N/1,000 $\mathrm{ft}^{2}$ or 35 $\mathrm{g} / \mathrm{cm}$ trunk caliper $(1.1 \mathrm{lb} / \mathrm{in})$.$] for white ash, 63 \mathrm{~g} / \mathrm{cm}$ (0.4 lb/in.) for honeylocust, and $67 \mathrm{~g} / \mathrm{cm}$ (4 lb/in.) trunk caliper for pin oak for in spring 1963 and again in 1964 and 1965. The different fertilizer application rates based on caliper are due to different initial caliper sizes among the three species. Foliage treatments were applied annually in May, June, and July. Each treatment was applied to one, five-tree row plot (one row of five trees). Plant caliper was measured annually for six years.

The largest caliper pin oaks were those treated with a complete fertilizer (N-P-K) placed in holes [9.75-cm (3.8-in.) caliper increase] and a complete fertilizer applied as a liquid fertilizer [9.84 cm (3.9 in.) caliper increase]. The smallest-caliper trees were those treated with foliar $\mathrm{N}$ and those without $\mathrm{N}$. The greatest difference in caliper increase was $3.3 \mathrm{~cm}$ (1.3 in.) after six years. Control trees increased in caliper by $6.86 \mathrm{~cm}$ (2.7 in.).

For white ash, the largest caliper increase was for trees fertilized with urea by soil solution $[8.01 \mathrm{~cm}$ (3.2 in.)]; the smallest increase was for those receiving $\mathrm{P}$ and $\mathrm{K}$ via soil solution [4.66 cm (1.8 in.)]. Unfertilized trees increased caliper by $5.38 \mathrm{~cm}$ (2.1 in.). For honeylocust, the largest caliper increase was for those trees treated with ammonium nitrate by soil solution [9.99 cm (3.9 in.)]; the smallest caliper increase was for those receiving foliar-applied $\mathrm{N}$ [3.86 cm (1.5 in.)]. Unfertilized trees increased caliper by $5.26 \mathrm{~cm}$ (2.1 in.).

One criticism of the study is that it was not replicated; each treatment was applied to one plot of five trees. Also, the results may be confounded by "shared" root zones. Tree roots from adjacent plots were likely growing in the same soil volume. The lack of tree response to fertilizer could also be attributed to good site quality and/or grass competition.

For the fertilizer type and application time study, a second block of 100 pin oaks was used. The pin oaks were established and grown similarly to those in the fertilizer type and method of application study. The experimental design was a factorial combination of fertilizer application times and fertilizer types. All fertilizers were surface-applied at the rate of $26.9 \mathrm{~g} \mathrm{~N} / \mathrm{m}^{2}$
[6 lb N/1,000 $\mathrm{ft}^{2}$ or $20 \mathrm{~g} / \mathrm{cm}(0.11 \mathrm{lb} /$ in.) trunk caliper]. Four fertilizer types were used: ammonium nitrate, ammonium sulfate, urea, and ureaform. Fertilizer was applied once in April; split between April and June; split between April, June, and October; once in October; and an unfertilized control treatment. Fertilizers were applied annually for three years; caliper growth was measured for five years. Five, single tree replications were used.

The largest-caliper pin oaks were those fertilized in April and those given a split application in April and June. However, the differences in tree growth among the fertilizer types were slight; the greatest difference was $0.66 \mathrm{~cm}$ (0.26 in.). The greatest difference between fertilized and control trees was $1.52 \mathrm{~cm}$ (0.6 in.). There were no treatment differences among $\mathrm{N}$ sources. There were no treatment differences in application time. The authors indicate that the promotive effect of fertilizer began to decrease within one or two years after application stopped. The linear positive slopes do not support this conclusion.

The third study, effect of fertilizer type and rate, was conducted on a block of 100 white ash. The block was established similarly to the other studies. A factorial combination of four fertilizer types (ammonium nitrate, ammonium sulfate, urea, and ureaform) and four rates [14.7, 29.3, 44.0, and $58.6 \mathrm{~g} \mathrm{~N} / \mathrm{m}^{2}(3,6,9$, and $12 \mathrm{lb} \mathrm{N} / 1,000 \mathrm{ft}^{2}$ ) or $6.6,13.0,19.9$, or $26.5 \mathrm{~g} / \mathrm{cm}$ caliper $(0.04,0.07,0.11$, or $0.15 \mathrm{lb} /$ in.) $]$ was used. Fertilizers were applied for two consecutive years; trunk caliper was measured for four years. All fertilizers were surface-applied in spring. Five individual tree replications per treatment were used.

The authors conclude that $29.3 \mathrm{~g} \mathrm{~N} / \mathrm{m}^{2}[6 \mathrm{lb} \mathrm{N} /$ $1,000 \mathrm{ft}^{2}(13.0 \mathrm{~g} / \mathrm{cm}$ caliper or $0.07 \mathrm{lb} / \mathrm{in}$.)] was the optimum rate and that there was no difference in fertilizer types. If their data from Table 17 are graphed, a different interpretation results. The optimum rate of ammonium nitrate appears to be $29.3 \mathrm{~g} \mathrm{~N} / \mathrm{m}^{2}$ [6 $\mathrm{lb}$ $\mathrm{N} / 1,000 \mathrm{ft}^{2}(13.0 \mathrm{~g} / \mathrm{cm}$ caliper or $\left.0.07 \mathrm{lb} / \mathrm{in}).\right]$; the optimum is $44.0 \mathrm{~g} \mathrm{~N} / \mathrm{m}^{2}$ [9 lb N/1,000 $\mathrm{ft}^{2}(19.9 \mathrm{~g} / \mathrm{cm}$ caliper or $0.11 \mathrm{lb} /$ in.)] for ureaform and more than $58.6 \mathrm{~g} \mathrm{~N} / \mathrm{m}^{2}\left[12 \mathrm{lb} \mathrm{N} / 1,000 \mathrm{ft}^{2}(26.5 \mathrm{~g} / \mathrm{cm}\right.$ caliper or $0.15 \mathrm{lb} / \mathrm{in})$.$] for urea and ammonium nitrate.$

\section{E. Smith}

Elton Smith (1991) conducted an 18-year fertilizer study with three species, Tilia cordata 'Select' (improved littleleaf linden), Malus 'Snowdrift' (Snowdrift 
Flowering Crabapple), and Acer saccharum 'Monumentale' (Sentry Sugar Maple). Trees were planted in species blocks on 20-by-20-ft spacing in a bluegrass sod. The soil type was not reported. A factorial combination of application type (drilled holes or surface) and $\mathrm{N}$ rate $\left[0,14.7,29.3\right.$, or $44.0 \mathrm{~g} \mathrm{~N} / \mathrm{m}^{2}\left(0,3,6\right.$, or $\left.\left.9 \mathrm{lb} \mathrm{N} / 1,000 \mathrm{ft}^{2}\right)\right]$ was applied to each species. Initial caliper size was not presented, so $\mathrm{N}$ application rates based on caliper cannot be calculated. Fertilizer was applied in spring once every three years. The controls were no holes with no fertilizer, and holes with no fertilizer. There were three, four-tree replications per treatment.

Smith reports that beginning at year six and by year nine, fertilizer treatment response began to decrease. When the results are graphed, the fertilizer response for linden began to decrease around year 16; for crabapple between years 10 and 12, and for maple about year 14 (data not presented). The fertilizer response may also diminish due to shared root zones and canopy closure. There have been no large empirical studies published since Smith's 1991 results.

The empirical studies previously described led to current shade tree fertilizer recommendations. The conclusions from these studies were summarized by Rose (1999):

- N source doesn't significantly affect growth.

- The recommended $\mathrm{N}$ rate application is 1 to 6 $\mathrm{lb} / 1,000 \mathrm{ft}^{2}\left(29.3 \mathrm{~g} \mathrm{~N} / \mathrm{m}^{2}\right)$. (Note: It was not possible to calculate the rate per unit caliper from Rose's data.)

- Surface application is as effective as soil injection or drilling treatments.

- Early spring and late fall $\mathrm{N}$ applications were effective times to apply fertilizer.

\section{MORE RECENT STUDIES}

Data questioning the physiological basis for some of these recommendations (especially the timing of $\mathrm{N}$ application) come from field and container studies with fruit crops using ${ }^{15} \mathrm{~N}$-labeled fertilizers. The seasonal pattern (Weinbaum et al. 1984) and uptake efficiency (Weinbaum et al. 1978) of nitrate absorption was demonstrated in two fruit crops through the use of ${ }^{15} \mathrm{~N}$-labeled nitrate fertilizer. Almond trees (Prunus dulcis) growing in either Turlock and Winters, California, U.S., were fertilized with ${ }^{15} \mathrm{~N}$-depleted ammonium sulfate in March, June, August, or December in orchards on a light and a heavy soil types (Weinbaum et al. 1984). ${ }^{15} \mathrm{~N}$-labeled fertilizer applied in spring accounted for $25 \%$ of the total foliage $\mathrm{N}$. The other $75 \%$ of the total $\mathrm{N}$ was absorbed during the previous growing season and stored and then translocated in spring to the new growth. The relative contribution of ${ }^{15} \mathrm{~N}$ in the foliage was reduced the later the labeled fertilizer was applied. Only $3 \%$ of the foliar $\mathrm{N}$ was labeled after the August fertilization treatment. The general conclusion was that soil-derived $\mathrm{N}$ fertilizer was partitioned preferentially into vegetative but not reproductive growth in the year of application. Additional $\mathrm{N}$ moves to storage pools to be recycled in the subsequent year to support the early stages of reproductive and vegetative growth. Nitrogen absorbed in summer is preferentially partitioned into storage pools to be used in the subsequent season's reproductive and vegetative growth.

In a study with containerized prune trees, seasonal nitrate utilization efficiency (total fertilizer $\mathrm{N}$ absorbed per tree per ten days divided by the total fertilizer $\mathrm{N}$ applied per tree per ten day and multiplied by 100) was lowest, about $4.5 \%$, in dormant trees and trees undergoing bud swell (Weinbaum et al. 1978). Nitrogen utilization efficiency (NUE) was highest when plants had leaves; it then ranged from 30\% to $39 \%$ between the rapid shoot growth phase (late April) and September 30. It was low in November and December, $16 \%$ and $4 \%$ respectively. These data show the importance of leaves and current photosynthate to support root growth and nitrate- $\mathrm{N}$ uptake.

To the author's knowledge, no one study has explored the relationship among shoot and root growth, photosynthate translocation patterns, and $\mathrm{N}$ absorption. However, Huett (1996) synthesized the relationship in a $\mathrm{N}$ nutrition review. He states that crop productivity is dependent on an adequate $\mathrm{N}$ status because photosynthetic capacity is dependent on leaf $\mathrm{N}$ content per unit area. Efficient $\mathrm{N}$ uptake occurs during periods of active growth and depends on active photosynthesis. Most $\mathrm{N}$ in exposed leaves is accumulated as protein, and the uptake and conversion to protein requires a carbohydrate $(\mathrm{CHO})$ supply. Thus, during periods of active shoot growth, when shoots represent a stronger $\mathrm{CHO}$ sink than roots, $\mathrm{N}$ uptake is limited by inadequate $\mathrm{CHO}$ supply. Nitrogen uptake potential increases between shoot flushes when leaves are net exporters of $\mathrm{CHO}$. Increased $\mathrm{CHO}$ supply to the roots stimulates root growth and $\mathrm{N}$ absorption. Nitrogen export to the shoot stimulates a flush of shoot growth and the al- 
ternating cycle of shoot and root growth and $\mathrm{N}$ absorption repeats.

The cyclic pattern of root and shoot growth, with corresponding increases in root $\mathrm{N}$ concentration during periods of shoot rest and decreases in root $\mathrm{N}$ concentration during shoot growth, has been demonstrated in 'Helleri' holly (Gilliam and Wright, 1978a,b; Mertens and Wright 1978; Yeager et al. 1980), Euonymus japonica (Hershey and Paul 1983), and Ligustrum japonicum (Kuehny and Decoteau 1994). Nitrogen absorption is low during leafless periods because of lack of photosynthate.

Subsequent studies support Weinbaum's $\mathrm{N}$ uptake and storage patterns with fruit crops, and Huett's synthesis. Spring-applied $\mathrm{N}$ is partitioned to leaves and storage pools in the year of application, whereas summer- and fall-applied $\mathrm{N}$ is partitioned to storage pools (typically in roots) in the year of application and translocated to the shoot to support vegetative and reproductive growth the following season (Meyer and Tukey 1965; van de Werken 1981; Pregitzer et al. 1990; Millard and Proe 1991; Proe and Millard 1995; Marmann et al. 1997; Toselli et al. 2000; Craig 2001; Dong et al. 2001; Neilsen et al. 2001). Nitrogen use efficiency (NUE) is relatively low in spring (before budbreak) and high in summer (Struve 1995; Sung et al. 1997; Struve and Rose 1998; Dong et al. 2001; Neilsen et al. 2001; Larimer and Struve 2002). Also, low soil temperatures contribute to reduced NUE in spring (Meyer and Tukey 1967; Good and Tukey 1969; Dong et al. 2001).

Rose (1999) reviewed fertilizer recommendations for woody plants in field nurseries and landscape sites. Nitrogen application rates ranged from 4.9 to $29.3 \mathrm{~g} \mathrm{~N} / \mathrm{m}^{2}$ ( 1 to $\left.6 \mathrm{lb} \mathrm{N} / 1,000 \mathrm{ft}^{2}\right)$. Many of the recommendations were for early spring (before budbreak) or late fall $\mathrm{N}$ applications, during periods of low $\mathrm{N}$ uptake potential. Rose (1999) asks, if $\mathrm{N}$ uptake potential/ efficiency is low and the potential for leaching high during these periods, why do these recommendations persist? The potential for $\mathrm{N}$ loss to leaching with spring fertilizer applications is less if the tree is growing in a lawn situation than if the soil beneath the tree is unmulched and clean cultivated. Bluegrass sod has a high potential for rapid absorption of spring-applied N (Miltner et al. 1996). Within 18 days of application, $31 \%$ of the labeled $\mathrm{N}$ was recovered in the thatch. If clippings are not removed, the $\mathrm{N}$ in thatch represents a slow-release source of $\mathrm{N}$, which becomes increasingly available as seasonal temperatures and thatch decomposition rates increase. Thus, spring-applied $\mathrm{N}$ may become available to trees in summer when tree mineral nutrient uptake potential is highest. Although the logic behind early spring $\mathrm{N}$ fertilizer application is faulty for trees under clean cultivation, it may be an environmentally responsible practice for fertilizing trees growing in sod where grass clippings are not removed.

Recent concern about the effects of high $\mathrm{N}$ applications on plant health and environmental quality have caused a reevaluation of fertilizer practices (Miller 1998, 2000). High $N$ applications reduce the concentration of defensive compounds, increasing the tree's susceptibility to certain pests (Herms and Mattson 1992). However, high fertility increases growth rate and often results in nutrient loading. $\mathrm{Nu}-$ trient loading is defined as an increase in the seedling's nutrient concentration without a significant increase in dry weight (Malik and Timmer 1995). Nutrient-loading conifer seedlings increased planting stock quality; they established more rapidly on stressful sites than non-nutrient loaded seedlings (Malik and Timmer 1995, 1998; Paquin et al., 2000; Imo and Timmer 2001). Lower concentrations of defensive compounds caused by high fertility levels during production can be compensated for by pesticide applications, which act as surrogates for naturally produced defensive compounds. However, the use of pesticides in landscape sites is not as easily done as in the production environment. The benefits of nutrient-load nursery stock planted in stressful urban sites needs to be tested.

The reason for fertilization is to supply nutrients determined to be deficient to achieve a clearly defined objective (ANSI 1998). The objectives include correcting a visible nutrient deficiency; eliminating a deficiency not readily visible that was detected through soil or tissue analysis; increasing plant growth, flowering, or fruiting; or to increase plant vitality (Smiley et al. 2002). Further, the fertilizer should be applied in the manner most beneficial to the plant (ANSI 1998). Before a mineral nutrition program is prescribed, the objective of the mineral nutrition program must be stated. If the goal is to maximize growth in the nursery, then soil fertility should be maintained in the high range (Darrah 2000; Smiley et al. 2002). However, if maintenance of an acceptable aesthetic level is the goal, as in a land- 
scape situation, then lower soil fertility levels are appropriate. In addition to meeting the aesthetic goal, low to moderate soil fertility would likely maintain natural plant defense mechanisms. The difficulty in meeting a fertilizer objective is that soil test calibrations [how much fertilizer needs to applied to effect the desired response (adjusted for soil type, species, and geographic region)] for the different management objectives (maintain vigor of old trees, maximize growth of recently established plants, or achieve rapid growth during production) are lacking for most woody ornamental species (Darrah 2000). Current N application standards are 1.0 to $1.5 \mathrm{~kg} / 100 \mathrm{~m}^{2}$ (2 to $3 \mathrm{lb} /$ $\left.1,000 \mathrm{ft}^{2}\right)$ to maintain mature tree vitality and 1.0 to $2.0 \mathrm{~kg} / 100 \mathrm{~m}^{2}$ (2 to $4 \mathrm{lb} / 1,000 \mathrm{ft}^{2}$ ) to increase growth of established small trees and higher levels (Smiley et al. 2002).

\section{SUMMARY}

Tree care professionals sensitive to environmental quality and tree health issues need to move toward prescriptive mineral nutrient programs. A prescriptive mineral nutrition program begins with soil testing and foliar nutrient analyses and a stated goal: increase in tree size, maintenance of an acceptable aesthetic level, or increase in tree vitality. Different soil fertility levels are needed to reach these goalshigher soil fertility for growth and lower for maintenance objectives. Unfortunately, soil test correlations for most tree species and soil types have not been developed. Additional research is needed in this area. Nitrogen is typically the limiting mineral nutrient. Current $\mathrm{N}$ application rates range from 4.9 to $29.3 \mathrm{~g}$ $\mathrm{N} / \mathrm{m}^{2}$ ( 1 to $\left.6 \mathrm{lb} \mathrm{N} / 1,000 \mathrm{ft}^{2}\right)$. This range of $\mathrm{N}$ fertilizer rates will be further defined as soil test correlations are developed. The $\mathrm{N}$ fertilizer type doesn't appear to be important. For deciduous trees, higher nitrogen use efficiency is realized if $\mathrm{N}$ is applied after budbreak than during the leafless, dormant season. Little difference has been found among fertilizer application methods; broadcast applications are as effective as subsurface applications. Additional research is needed with tree-lawn systems to define $\mathrm{N}$ uptake patterns, $\mathrm{N}$ uptake potential, and $\mathrm{N}$ cycling among the system's components.

\section{LITERATURE CITED}

American National Standards Institute (ANSI). 1998. American National Standard for Tree Care OperationsTree, Shrub, and Other Woody Plant MaintenanceStandard Practices (Fertilization). (A300, Part 2). American National Standards Institute, New York, NY.

Bielmann, A.P. 1929. Feeding of shade and ornamental trees. M. Bot. Gar. Bull. 17(8):119-130.

- 1934. How to feed a shade tree. M. Bot. Gar. Bull. 22(4):113-126.

- 1936. Feeding the shade trees. M. Bot. Gar. Bull. 24(4):95-118.

Chadwick, L.C. 1934. The fertilization of shade trees in the nursery. Am. Soc. Hortic. Sci. 32:357-360.

- 1936. Fertilizer trials with shade trees in the nursery. Am. Soc. Hortic. Sci. 34:664-668.

Chadwick, L.C., P.E. Tilford, and C.F. Irish. 1950. A study of some methods of fertilizing shade trees. Am. Soc. Hortic. Sci. 55:519-526.

Charlton, O.C. 1927. City of Dallas Park Department, Bull. No. 4., Cited in Bielmann, A.P. 1929. Feeding of shade and ornamental trees. M. Bot. Gar. Bull. 17(8):119-130.

Craig, J. 2001. Controlled-Release Fertilizer N Release Profile Effect on Nitrogen Uptake. M.S. thesis. The Ohio State University, Columbus, $\mathrm{OH}$.

Curlin, J.W. 1962. Dogwood responds to nitrogen fertilization. J. For. 60:718-719.

Darrah, C.H. 2000. Pp 21-27. In Siewert, A., A. Siewert, B. Rao, and D. Marion (Eds.). Tree and Shrub Fertilization. Proceedings from an International Conference on Tree and Shrub Fertilization. May 17-18, 2000. Fairlawn, OH.

Dong, S., C.F. Scagel, L. Cheng, L.H. Fuchigami, and P.T. Rygiewicz. 2001. Soil temperature and plant growth stage influence nitrogen uptake and amino acid concentration of apple during early spring growth. Tree Physiol. 21:541-547.

Finn, R.F., and C.P.White. 1966. Commercial fertilizers increase growth in a yellow-poplar plantation. J. For. 64:809-810.

Gilliam, C.H., and R.D. Wright. 1978a. Timing of fertilizer application in relation to growth flushes of 'Helleri' holly (Ilex crenata Thunb.). HortScience 13:300-301.

- 1978b. Effects of three nitrogen levels on tissue nitrogen fluctuation during a flush of growth on 'Helleri' holly (Ilex crenata Thunb.). HortScience 13:301-302.

Good, G.L., and H.B. Tukey. 1969. Root growth and nutrient uptake by dormant Ligustrum ibolium and Euonymus alatus 'Compactus'. J. Am. Soc. Hortic. Sci. 94:324-326.

Herms, D.A., and W.J. Mattson. 1992. The dilemma of plants: To grow or defend. Q. Rev. Biol. 67:283-335.

Hershey, R., and J.L. Paul. 1983. N absorption by a woody plant with episodic growth. HortScience 18:357-359.

Huett, D.O. 1996. Prospects for manipulating the vegetativereproductive balance in horticultural crops through nitrogen nutrition:A review. Aust. J.Agric. Res. 47:47-66. 
Imo, M., and V.R. Timmer. 2001. Growth and nitrogen retranslocation of nutrient loaded Picea mariana seedlings planted on boreal mixed wood sites. Can. J. For. Res. 31:1357-1366.

Kuehny,J., and D.R. Decoteau. 1994. Interrelationship of nitrogen and light on episodic growth of Ligustrum japonicum. J. Environ. Hortic. 12:43-46.

Larimer, J., and D. Struve. 2002. Growth, dry weight and nitrogen distribution of red oak and 'Autumn Flame' red maple under different fertility levels. J. Environ. Hortic. 20:28-35.

Malik, B., andV.R. Timmer. 1995. Interaction of nutrient-loaded black spruce seedlings with neighboring vegetation in greenhouse environments. Can. J. For. Res. 25:1017-1023.

_. 1998. Biomass partitioning and nitrogen retranslocation in black spruce seedlings on competitive mixed wood sites: A bioassay study. Can. J. For. Res. 28:206-215.

Marmann, P., R. Wendler, P. Millard, and H. Heilmeier. 1997. Nitrogen storage and remobilization in ash (Fraxinus excelsior) under field and laboratory conditions. Trees 11:298-305.

Mertens, W.C., and R.D. Wright. 1978. Root and shoot growth rate relationships of two cultivars of Japanese holly.J. Am. Soc. Hortic. Sci. 103:722-724.

Meyer, M.M., and H.B.Tukey. 1965. Nitrogen, phosphorus, and potassium plant reserves and the spring growth of Taxus and Forsythia. Proc. Amer. Soc. Hort. Sci. 87:537-544.

Meyer, M.M., and H.B. Tukey. 1967. Influence of root temperature and nutrient applications on root growth and mineral nutrient content of Taxus and Forsythia plants during the dormant season. Proc. Amer. Soc. Hort. Sci. 90:440-442.

Millard, P., and M.F. Proe. 1991. Leaf demography and the seasonal internal cycling of nitrogen in sycamore (Acer pseudoplatanus L.) seedlings in relation to nitrogen supply. Tree Physiol. 117:587-596.

Miller, R.W. 1998. Tree fertilization, science, myth and ethics. Arborist News 7(6):26-27.

-2000. Practical applications: Are we asking the right questions and looking in the right places. In Siewert, A., A. Siewert, B. Rao, and D. Marion (Eds.). Tree and Shrub Fertilization. Proceedings from an International Conference on Tree and Shrub Fertilization. May 1718, 2000. Fairlawn, OH.

Miltner, E.D., B.E. Branham, E.A. Paul, and P.E. Rieke. 1996. Leaching and mass balance of ${ }^{15} \mathrm{~N}$-labeled urea applied to a Kentucky bluegrass turf. Crop Sci. 36:1427-1433.

Moeller, A. 1908. Die Nutzbarmachung des Rohhumu (Trockentorf). Zeitschrift fur Forst- und Jagdwesen 40:273-290. Cited in Bielmann, A.P. 1929. Feeding of shade and ornamental trees. M. Bot. Gar. Bull. 17(8). 119-130.

Mulford, F.L. 1937. Planting and Care of Street Trees. USDA Farmers' Bull. No. 1209.29 pp.

Neely, D., E.B. Himelick, and W.R. Crowley, Jr. 1965. Experimental field studies on shade tree fertilization. Ill. Nat. Hist. Sur. Biol. Notes No. 53.
- 1970. Fertilization of established trees: A report of field studies. Ill. Nat. Hist. Sur. Bull. 53(4).

Neilsen, D., P. Millard, L.C. Herbert, G.H. Neilsen, E.J. Hogue, P. Parchomchuk, and B.J. Zebarth. 2001. Remobilization and uptake of $\mathrm{N}$ by newly planted apple (Malus domestica) trees in response to irrigation method and timing of $\mathrm{N}$ application. Tree Physiol. 21:513-521.

Paquin, R., H.A. Margolis, R. Doucet, and M.R. Coyea. 2000. Physiological responses of black spruce layers and planted seedlings to nutrient addition. Tree Physiol. 20:229-237.

Pridham, A.M.S. 1938. Growth of pin oak (Quercus palustris)—Report of seven years' observation. Am. Soc. Hortic. Sci. 35:739-741.

— 1940. Response of mature American elm to ammonium sulfate as a fertilizer. Am. Soc. Hortic. Sci. 37:1075-1076.

—. 1941. Response of red oak to fertilization with ammonium sulfate. Am. Soc. Hortic. Sci. 39:439.

Pregitzer, K.S., D.I. Dickmann, R. Hendrick, and P.V. Nguyen. 1990. Whole-tree carbon and nitrogen partitioning in young hybrid poplars. Tree Physiol. 7:79-93.

Proe, M.F., and P. Millard. 1995. Effect of N supply upon the seasonal partitioning of $\mathrm{N}$ and $\mathrm{P}$ uptake in young Sitka spruce (Picea sitchensis). Can. J. For. Res. 25:1704-1709.

Rose, M.A. 1999. Nutrient use patterns in woody perennials: Implications for increasing fertilizer efficiency in field-grown and landscape ornamentals. HortTechnology 9:613-617.

Siewert, A., A. Siewert, B. Rao, and D. Marion. 2000. Tree and Shrub Fertilization. Proceedings from an International Conference on Tree and Shrub Fertilization. May 17-18, 2000. Fairlawn, OH.

Smiley, E.T., S.J. Lilly, and P. Kelsey. 2002. Best Management Practices: Tree and Shrub Fertilization. International Society of Arboriculture, Champaign, IL.

Smith, E.M. 1991. Fertilizing trees in the landscape: An 18year evaluation. OARDC Spec. Circ. 135. Ornament. Plants. A summary of research. 27-29.

Struve, D.K. 1995. Nitrogen, phosphorus and potassium recovery of container-grown red oak and blackgum seedlings under different fertilizer application methods. J. Environ. Hortic. 13:169-175.

Struve, D.K., and M.A. Rose. 1998. Early-season fertilization reduces fertilizer use without reducing plant growth. J. Environ. Hortic. 16:47-51.

Sung, S.S., C.C. Black, T.L. Kormanik, S.J. Zarnoch, P.P. Kormanik, and P.A. Counce. 1997. Fall nitrogen fertilization and the biology of Pinus taeda seedling development. Can. J. For. Res. 27:1406-1412.

Toselli, M., J.A. Flore, C. Zavalloni, and B. Marangoni. 2000. Nitrogen partitioning in apple trees as affected by application time. HortTechnology 10:136-141.

van de Werken, H. 1981. Fertilization and other factors enhancing the growth rate of young shade trees. J. Arboric. 7:33-37. 
Weinbaum, S.A., M.L. Merwin, and T.T. Muraoka. 1978. Seasonal variation in nitrate uptake efficiency and distribution of absorbed nitrogen in non-bearing prune trees. J.Am. Soc. Hortic. Sci. 103:515-519.

Weinbaum, S.A., I. Klein, F.E. Broadbent, W.C. Micke, and T.T. Muraoka. 1984. Effects of time of nitrogen application and soil texture on the availability of isotopically labeled fertilizer nitrogen to reproductive and vegetative tissue of mature almond trees. Am. Soc. Hortic. Sci. 109:339-343.

Wyman, D. 1936. Growth Experiments with Pin Oaks Which are Growing Under Lawn Conditions. Cornell Univ. Agric. Exp. Sta. Bull. 646.

Yeager, T.H., R.D. Wright, and M.M. Alley. 1980. Response of Ilex crenata Thunb. vs. Helleri to timed fertilizer applications. J. Am. Soc. Hortic. Sci. 105:213-215.

Acknowledgments. Salaries and research support provided by state and federal funds appropriated to the Ohio Agriculture Research and Development Center. The Ohio State University. Manuscript number HCS 01-39.

\section{Department of Horticulture and Corp Science}

The Ohio State University

Columbus, OH 43210, U.S.

Résumé. La recherche aux États-Unis dans le domaine de la fertilisation azotée des arbres ornementaux, qui a débutée dans les années 20, a été revue. Les études empiriques récentes démontrent que la croissance des arbres ornementaux augmente avec l'application d'azote, que la source d'origine de l'azote n'affecte pas significativement la croissance, que l'application en surface est aussi efficace que l'injection ou le forage dans le sol, et que l'application d'azote à des taux de $29 \mathrm{~g} / \mathrm{m} 2$ (6 lbs./100 pi. $\left.{ }^{2}\right)$ est à peu près le niveau optimal. De même, les résultats de ces études recommandent une application durant les périodes de dormance (tôt au printemps, tard en automne). Les arbres dans ces études ont été plantés dans des espaces relativement restreints et les expériences ont été menées sur de longues périodes. De ce fait, les résultats se confondaient entre eux en raison du partage mutuel des mêmes zones d'enracinement. En raison de la croissance racinaire hors des zones de traitements et dans des unités adjacentes, les racines d'un même arbre pouvaient être exposées à deux traitements ou plus. Deux facteurs additionnels amenant de la confusion étaient que plusieurs études ont été menées sur des sols établis ayant un haut degré de fertilité indigène, et aussi que les plantes herbacées entraient en compétition pour l'eau et les éléments minéraux. Ceci pourrait expliquer l'absence générale de différences entre les traitements dans ces études. De nouvelles études menées avec l'azote montrèrent une faible assimilation d'azote durant la période dormance (sans feuilles), remettant dès lors en question la pratique des applications durant la saison de dormance.

Zusammenfassung. Die amerikanische Forschung über die Düngung von Schattenbäumen seit 1920 wird hier betrachtet. Die frühen empirischen Studien demonstrierten, dass das Wachstum von Schattenbäumen anstieg in Reaktion auf $\mathrm{N}$ Applikation, dass der Wachstumseffekt nicht von der N-Quelle ausgeht, dass die Oberflächenapplikationen so effektiv wie Bodeninjektionen oder Bohrungen waren und dass NApplikationen von $29 \mathrm{~g} \mathrm{~N} / \mathrm{m}^{2}$ optimal schienen. Resultierend aus diesen Studien wurden Empfehlungen für die $\mathrm{N}$ Applikation in der schlafenden Saison gegeben. Die Bäume wurden mit relativ dichten Abständen gepflanzt und die Experimente einen langen Zeitraum begleitet. Daher wurden die Ergebnisse beeinflusst durch das überlappende Wurzelwachstum. Wegen des Wurzelwachstums aus den beobachteten Flächen in benachbarte Flächen konnten die Wurzeln eines einzelnen Baumes erst in 2 oder mehr Behandlungen exponiert werden. Zwei zusätzliche Faktoren waren, dass viele Studien auf Böden mit hoher natürlicher Fruchtbarkeit durchgeführt und dass Grasbewuchs als Konkurrent für Wasser und Nährstoffe präsent war. Das mag die generelle Abwesenheit von Behandlungsunterschieden in diesen Studien erklären. Spätere Studien mit N zeigten niedrige N-Aufnahme während der blattlosen Saison, was die Frage nach der Düngung in der vegetationsarmen Zeit aufwirft. Zusätzliche

Resumen. Se revisa la fertilización nitrogenada de árboles de sombra en los Estados Unidos, iniciada en los 1920s. Los primeros estudios empíricos demostraron que el crecimiento de los árboles de sombra incrementó en respuesta a las aplicaciones de $\mathrm{N}$; que la fuente de $\mathrm{N}$ no afectó significativamente el crecimiento; que las aplicaciones superficiales fueron tan efectivas como las inyecciones al suelo o perforaciones, y que las tasas de aplicaciones de $\mathrm{N}$ de $29 \mathrm{~g} \mathrm{~N} / \mathrm{m}^{2}\left(6 \mathrm{lb} / 100 \mathrm{ft}^{2}\right)$ fueron cercanas al óptimo. También, como resultado de los estudios se hicieron recomendaciones para la estación de dormancia (primavera temprana, otoño tardío) como la época de aplicación. Los árboles en estos estudios fueron plantados en espacios relativamente estrechos con "zonas de raíces compartidas". Debido al crecimiento de las raíces fuera de las áreas "tratadas" y dentro de parcelas adyacentes, las raíces de un mismo árbol pudieron estar expuestas a dos o más tratamientos. Dos factores adicionales de confusión fueron que muchos estudios se establecieron en suelos con alta fertilidad nativa y que los pastos compitieron por agua y minerales. Esto puede explicar la ausencia general de diferencias de los tratamientos en estos estudios. Estudios posteriores conducidos con ${ }^{15} \mathrm{~N}$ mostraron baja absorción de $\mathrm{N}$ durante la estación de dormancia (sin hojas), cuestionando la práctica de las aplicaciones de $\mathrm{N}$ durante la dormancia. 


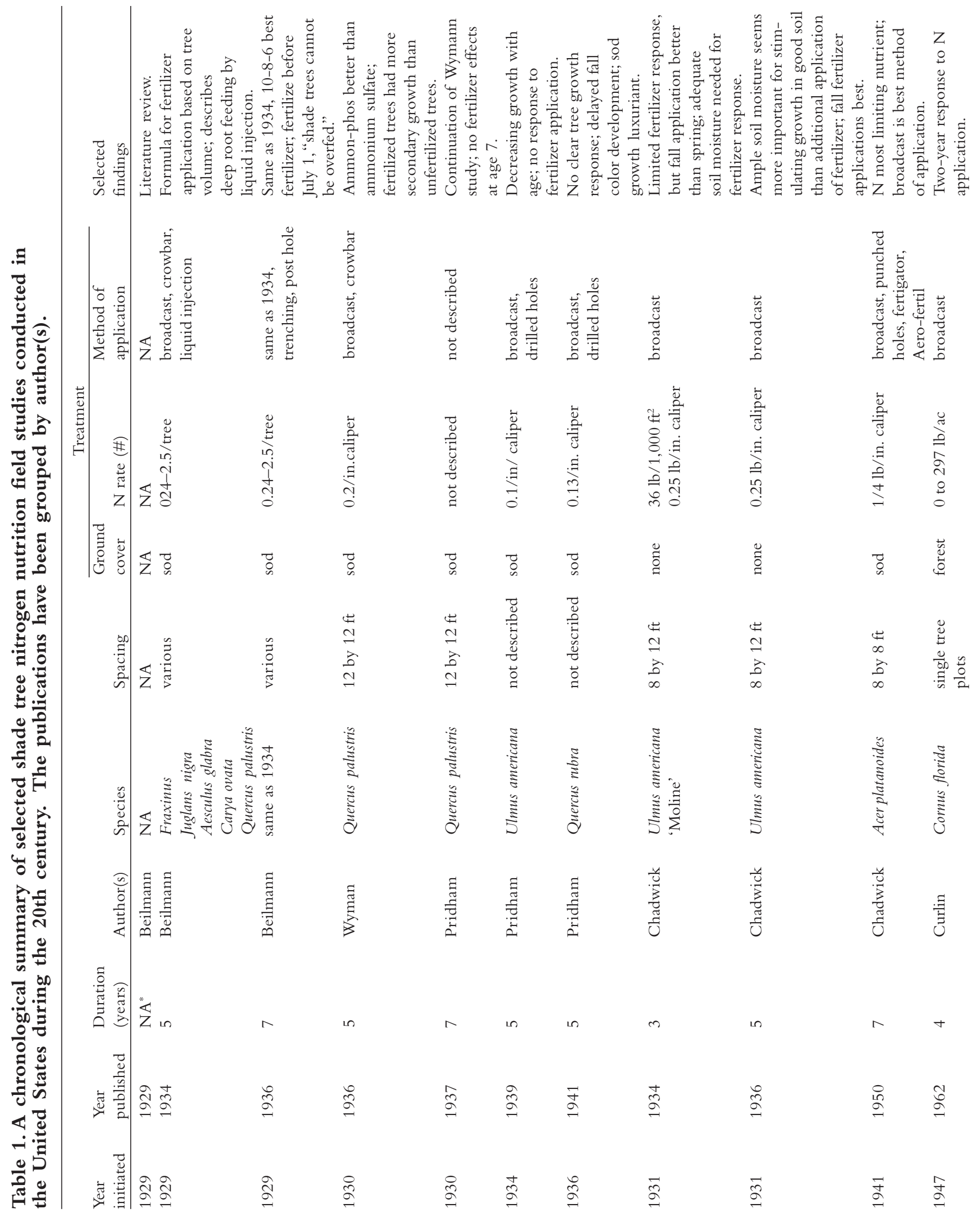



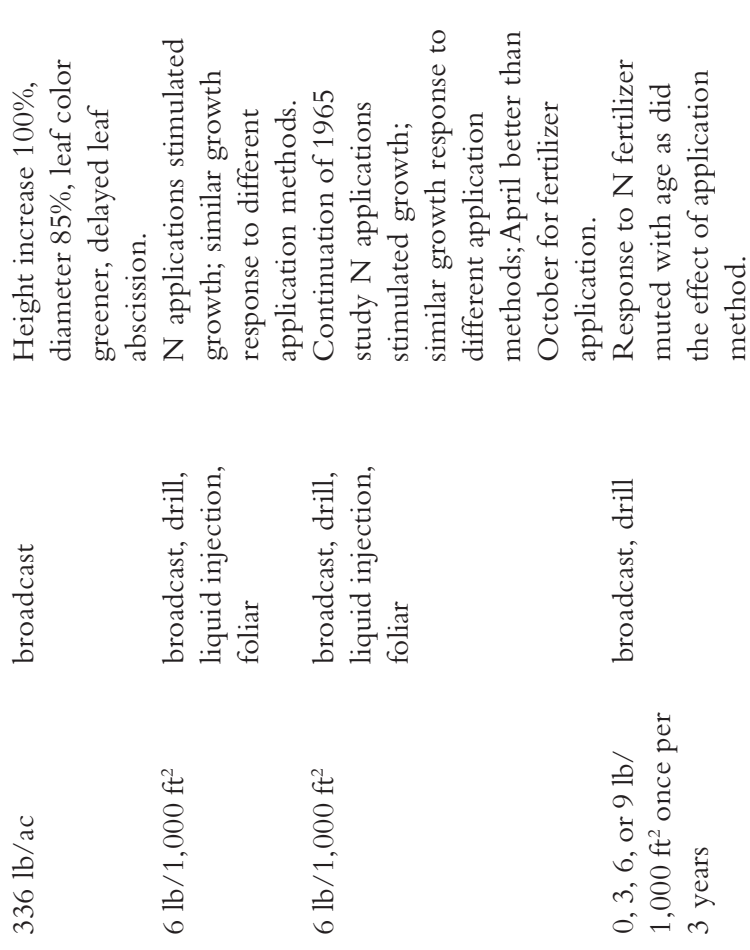

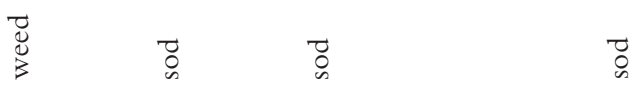

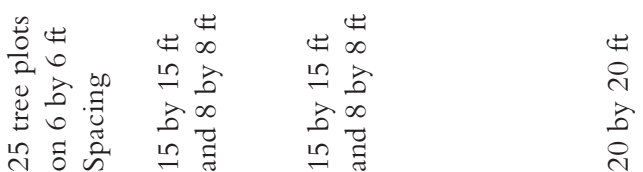
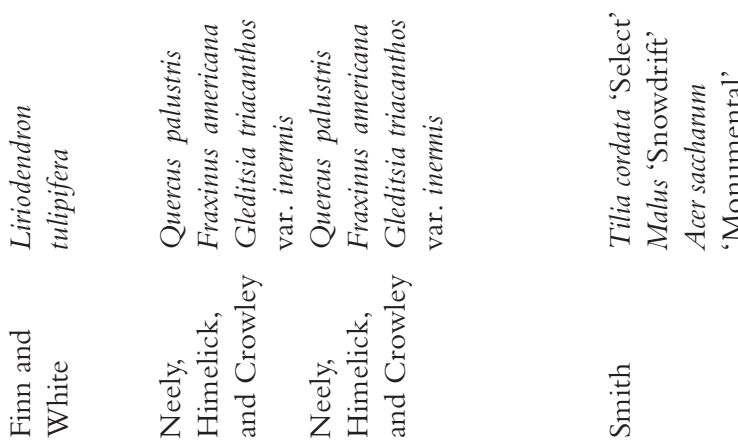

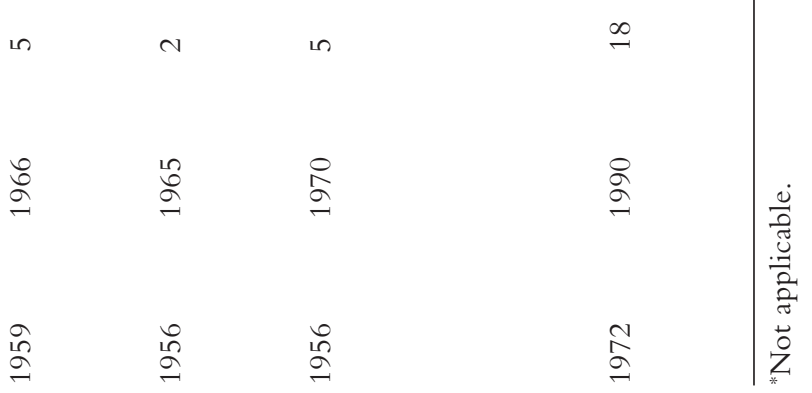

